E-ISSN : 2549-6581

Artikel Hasil Penelitian

OPEN ACCESS

Diterima : 2 Juli 2018

Direview : 2 Juli 2019

Dimuat : April 2019 - Juli 2019

\title{
Hubungan Pemberian Air Susu Ibu (ASI) dengan Perubahan Persentase Lemak Tubuh pada Ibu Menyusui di Wilayah Kerja Puskesmas Arjuno Kota Malang pada Bulan November 2017- Februari 2018
}

\author{
Miftakhul Khasanah ${ }^{1)}$, Era Nurisa Windari ${ }^{2}$, Catur Saptaning Wilujeng ${ }^{3}$ \\ 1)Program Studi S1 Kebidanan, Fakultas Kedokteran, Universitas Brawijaya Email: \\ miftakhulk28@gmail.com Tlp : 089696906285 \\ ${ }^{2}$ Program Studi S1 Kebidanan, Fakultas Kedokteran, Universitas Brawijaya Email: \\ ersawibowo@gmail.com \\ ${ }^{3}$ Program Studi S1 Gizi, Fakultas Kedokteran, Universitas Brawijaya, Email: \\ catursaptaning@gmail.com
}

\begin{abstract}
During pregnancy there will be metabolic changes due to physiological responses arising from the fetus and placenta. As a result of these metabolic changes one of them is weight gain. This increase in body weight is caused by the body tissues of the mother's blood, extracellular fluids, uterus, breast, and fat. In addition, pregnancy products such as fetus, amniotic fluid and placenta. Breastfeeding can reduce the fat reserves that have been made during pregnancy because the fat reserves are used to produce energy in producing breast milk. This study aims to determine the relationship of breastfeeding with the percentage change in body fat in breastfeeding mothers in Arjuno Health Center Malang. This study used a cohort study design with the number of samples of 44 breastfeeding mothers who are in the Arjuno Health center Malang. Researchers followed a group of mothers who breastfed exclusively and non-exclusively for 2 months. Percentage of body fat mother measured as much as 2 times that is beginning of research and end of research by using Bioelectrical Impedance Analysis (BIA). Breastfeeding data for infants is observed through telephone interviews once a week. The results showed mothers who gave exclusive breastfeeding decreased body fat percentage as much as $31.8 \%$ and mothers who increased body fat percentage as much as $18.2 \%$. In contrast, mothers who did not give exclusive breastfeeding increased the percentage of body fat as much as $43.2 \%$ and mothers who decreased body fat percentage as much as $6.8 \%$. The result of Chi-square test that $p$ value $=0,001$ and relative risk 2,37 means that mother giving non-exclusive breastfed have chance to increase body fat percentage 2,37 compared to mother giving exclusive breastfeeding. The conclusion in this research is there is correlation between breastfeeding with change of body fat percentage in breastfeeding mother in Arjuno Health Center Malang.
\end{abstract}

Key words: Breastfeeding, Percentage of body fat. 


\begin{abstract}
ABSTRAK
Selama kehamilan akan terjadi perubahan metabolik karena adanya respon fisiologis yang ditimbulkan dari janin maupun plasenta. Akibat dari perubahan metabolik salah satunya adalah kenaikan berat badan. Peningkatan berat badan ini disebabkan oleh jaringan tubuh ibu yaitu darah, cairan ekstrasel, uterus, payudara, serta lemak. Selain itu, produk kehamilan seperti janin, cairan amnion serta plasenta. Pemberian air susu ibu (ASI) dapat mengurangi cadangan lemak yang telah dibuat selama hamil karena dengan menyusui cadangan lemak tersebut digunakan untuk menghasilkan energi dalam memproduksi air susu ibu. Penelitian ini bertujuan untuk mengetahui hubungan pemberian air susu ibu dengan perubahan persentase lemak tubuh pada ibu menyusui di wilayah kerja Puskesmas Arjuno Kota Malang. Penelitian ini menggunakan disain penelitian cohort study dengan jumlah sampel sebanyak 44 ibu menyusui yang berada di wilayah kerja Puskesmas Arjuno Kota Malang. Peneliti mengikuti sekelompok ibu yang menyusui baik eksklusif maupun non-eksklusif selama 2 bulan. Persentase lemak tubuh ibu diukur sebanyak 2 kali yaitu awal penelitian dan akhir penelitian dengan menggunakan Bioelectrical Impedance Analysis (BIA). Data pemberian ASI kepada bayi diobservasi secara wawancara melalui telefon setiap satu minggu sekali. Hasil penelitian menunjukkan ibu yang memberikan ASI eksklusif mengalami penurunan persentase lemak tubuh sebanyak $31,8 \%$ dan ibu yang mengalami kenaikan persentase lemak tubuh sebanyak $18,2 \%$. Sebaliknya pada ibu yang tidak memberikan ASI eksklusif mengalami peningkatan persentase lemak tubuh sebanyak $43,2 \%$ dan ibu yang mengalami penurunan persentase lemak tubuh sebanyak 6,8\%. Hasil dari uji Chi-square didapatkan nilai $p=0,001$ dan nilai relative risk sebesar 2,37 artinya ibu yang memberikan ASI eksklusif memiliki peluang untuk menurunkan persentase lemak tubuh sebesar 6,8\% dibandingkan ibu yang memberikan ASI secara non-eksklusif. Kesimpulan dalam penelitian ini adalah terdapat hubungan antara pemberian air susu ibu (ASI) dengan perubahan persentase lemak tubuh pada ibu menyusui di wilayah kerja Puskesmas Arjuno Kota Malang.
\end{abstract}

Kata kunci: Pemberian ASI, Persentase lemak tubuh.

*Korespondensi: Miftakhul Khasanah. Surel: miftakhulk28@gmail.com

\section{PENDAHULUAN}

Air susu ibu (ASI) merupakan makanan yang paling baik bagi bayi sampai usia 6 bulan pertama kehidupan. Kebutuhan nutrisi yaitu protein, karbohidrat, lemak, vitamin, serta mineral seluruhnya terdapat di dalam ASI (Fikawati et al, 2015). Berbagai zat gizi yang terkandung didalam ASI sangat berguna untuk tumbuh kembang bayi serta dapat meningkatkan kecerdasan pada bayi. Selain itu, ASI juga mengandung antibodi yang dapat mencegah bayi dari infeksi sehingga bayi tidak mudah terkena penyakit (Maryam, 2016).
Menyusui secara eksklusif merupakan pemberian ASI saja kepada bayi sedini mungkin setelah persalinan tanpa memberikan makanan atau minuman tambahan selain ASI sampai bayi berusia 6 bulan. Setelah 6 bulan pemberian ASI dapat diberikan sampai bayi berusia dua tahun dengan ditambahkan makanan pendamping ASI (Purwanti, 2004). Menurut kajian global The Lancet Breastfeeding Series, dijelaskan bahwa menyusui eksklusif dapat menurunkan angka kematian karena infeksi sebanyak $88 \%$ pada bayi dengan usia kurang dari 3 bulan dan sebanyak $31,36 \%$ dari $37,94 \%$ anak 
sakit, disebabkan karena tidak menerima ASI eksklusif (Kemenkes RI, 2016).

Di Indonesia pada tahun 2016 berdasarkan data dari Ditjen Kesehatan Masyarakat RI, persentase bayi yang mendapatkan ASI eksklusif sampai umur 6 bulan sebesar 29,5\%. Sedangkan bayi yang mendapatkan ASI eksklusif pada umur 0-5 bulan sebesar $54,0 \%$. Angka tersebut masih belum mencapai target yang telah ditetapkan, dimana untuk pemberian ASI eksklusif sampai usia 6 bulan targetnya adalah $42 \%$ namun untuk pemberian ASI eksklusif pada umur 0-5 bulan telah mencapai target yang ditetapkan yaitu 54,0\% (Kemenkes RI, 2016). Di Kota Malang pada tahun 2016, cakupan pemberian ASI eksklusif mencapai $75,27 \%$. Apabila mengacu pada target cakupan pemberian ASI di Jawa Timur, masih belum mencapai target yang telah ditetapkan yaitu $77 \%$. Hal tersebut menunjukkan bahwa masih kurangnya kesadaran pentingnya pemberian ASI eksklusif bagi kesehatan bayi (Kemenkes RI, 2017).

Selama kehamilan akan terjadi perubahan baik fisiologi maupun anatomis pada ibu hamil. Perubahan tersebut disebabkan karena adanya respon fisiolgis dari janin maupun plasenta. Perubahanperubahan tersebut salah satunya adalah perubahan metabolik. Akibat dari perubahan metabolik tersebut akan terjadi kenaikan berat badan ibu. Peningkatan berat badan ini disebabkan oleh jaringan tubuh ibu yaitu darah, cairan ekstrasel, uterus, payudara, serta lemak. (Cunningham et al., 2012).

Pemberian air susu ibu (ASI) dapat membantu ibu dalam menurunkan berat badan. Dengan menyusui cadangan lemak selama hamil ditubuh ibu digunakan untuk menghasilkan energi untuk memproduksi ASI, sehingga secara tidak langsung membantu ibu dalam menurunkan berat badan. Untuk menghasilkan ASI sebanyak $850 \mathrm{cc}$ dibutuhkan energi sebesar rata-rata 750 kkal. Apabila dalam diet tetap ditambahkan 500 kkal, maka yang terkonversi hanya 400-450 kkal, berarti untuk mencukupi kekurangan tersebut setiap harinya harus dimobilisasi cadangan energi endogen sebesar 33-38 gr lemak. Dengan demikian simpanan lemak selama hamil sebanyak $4 \mathrm{~kg}$ akan habis setelah 3,5-4 bulan (Arisman, 2009). Sehingga dengan meningkatnya kebutuhan energi untuk produksi ASI tersebut dimana cadangan lemak dalam tubuh juga dipakai maka akan mengakibatkan perubahan persentase lemak tubuh yaitu akan terjadi penurunan pada persentase lemak dalam tubuh ibu.

Penelitian sebelumnya menyebutkan bahwa wanita yang menyusui secara eksklusif selama 6-11,9 bulan pertama setelah melahirkan berhubungan dengan penurunan persen lemak tubuh dan wanita yang menyusui secara eksklusif mengalami penurunan lebih besar persentase lemak tubuh dibandingkan dengan wanita yang memberi ASI parsial atau hanya memberikan susu formula saja kepada bayinya (Gigante, 2001). Penelitian lain menyebutkan bahwa rata-rata pada 6 minggu postpartum ketebalan lemak tubuh lebih rendah pada wanita yang menyusui bayinya secara eksklusif dibandingkan dengan wanita yang menyusui noneksklusif (Sidebottom, 2000). 


\begin{abstract}
Berdasarkan uraian diatas, maka peneliti ingin meneliti hubungan pemberian air susu ibu (ASI) dengan perubahan persentase lemak tubuh pada ibu menyusui di wilayah kerja Puskesmas Arjuno Kota Malang.
\end{abstract}

\section{METODE PENELITIAN Rancangan/Desain Penelitian}

Penelitian ini merupakan penelitian observasional analitik dengan disain penelitian cohort study. Dalam penelitian ini, peneliti akan mengikuti ibu yang menyusui (eksklusif dan non-eksklusif) selama 2 bulan kemudian dilihat perubahan persentase lemak tubuhnya meningkat atau menurun.

\section{Sasaran Penelitian (Populasi/Sampel/Subjek Penelitian)}

Populasi dalam penelitian ini adalah semua ibu yang menyusui bayinya dengan usia bayi $\leq 6$ bulan di wilayah kerja Puskemas Arjuno Kota Malang. Jumlah sampel dalam penelitian ini adalah 44 ibu menyusui yang dipilih dengan menggunakan teknik pengambilan sampel purposive sampling.

Kriteria inklusi dari penelitian ini adalah ibu yang tinggal di wilayah kerja Puskesmas Arjuno Kota Malang, ibu yang memiliki bayi usia 0-4 bulan, serta ibu rumah tangga yang hanya mengurus sepenuhnya anaknya dirumah. Sedangkan kiriteria eksklusi dari penelitian ini adalah ibu yang menggunakan obatobatan untuk menurunkan berat badan, ibu dengan riwayat penyakit kronis, serta ibu yang memiliki masalah selama menyusui. Kriteria drop out dalam penelitian ini adalah ibu yang menyusui eksklusif kemudian pada saat penelitian menghentikan pemberian ASI eksklusif, dan ibu yang mengundurkan diri selama penelitian berlangsung.

\section{Pengembangan Instrumen dan Teknik Pengumpulan Data}

Peneliti mengumpulkan data primer yaitu karakteristik responden, pemberian ASI serta persentase lemak tubuh. Data karakteristik responden diperoleh dari wawancara kepada responden kemudian data tersebut dimasukkan dalam lembar karakteristik responden. Data pemberian ASI diobservasi secara langsung dengan wawancara kepada responden setiap 1 minggu sekali selama dua bulan dari awal penelitian sampai akhir penelitian melalui via telefon dan data tersebut akan dimasukkan dalam lembar observasi pemberian ASI. Data persentase lemak tubuh didapatkan dari hasil pengukuran dengan menggunakan alat pengukur lemak tubuh yaitu Bioelectrical Impedance Analysis (BIA) HBF-358 BW dimana diukur 2 kali yaitu awal penelitian dan 2 bulan setelahnya untuk melihat perubahan dari persentase lemak tubuh. Hasil pengukuran persentase lemak tubuh nantinya akan dimasukkan kedalam lembar observasi persentase lemak tubuh.

\section{Teknik Analisis Data}

Analisis univariat dilakukan untuk menggambarkan data karakteristik responden yaitu usia ibu, usia bayi, pendidikan ibu, jenis kelamin bayi, berat badan lahir bayi, usia kehamilan ketika bayi lahir, pemeberian ASI, paritas serta persentase lemak tubuh.

Analisis bivariat dilakukan untuk mengetahui hubungan antara 
pemberian air susu ibu (ASI) dengan perubahan persentase lemak tubuh pada ibu menyusui. Data yang diperoleh kemudian dianalisis dengan menggunakan uji statistik Chi-square dengan interval kepercayaan sebesar $95 \% \quad \alpha=0,05$ dan hasil penelitian dikatakan bermakna apabila $p<0,05$.

Data Karakteristik Dasar Tabel 1.1 Data Karakteristik Ibu

\begin{tabular}{ccc}
\hline Usia lbu & $\mathbf{N}$ & $\%$ \\
\hline$<20$ tahun & 1 & 2 \\
$20-25$ tahun & 9 & 21 \\
$26-30$ tahun & 16 & 36 \\
$31-35$ tahun & 8 & 18 \\
$>35$ tahun & 10 & 23 \\
Jumlah & 44 & 100 \\
\hline Pendidikan lbu & $\mathbf{N}$ & $\%$ \\
\hline SD & 3 & 7 \\
SMP/MTS & 3 & 7 \\
SMA/SMK/MAN & 25 & 57 \\
D1/D2/D3 & 7 & 16 \\
S1/S2/S3 & 6 & 13 \\
Jumlah & 44 & 100 \\
\hline Paritas Ibu & $\mathbf{N}$ & $\%$ \\
\hline Primipara & 18 & 41 \\
Multipara & 24 & 55 \\
Grandemultipara & 2 & 4 \\
Jumlah & 44 & 100 \\
\hline Usia Kehamilan Ketika Bayi Lahir & $\mathbf{N}$ & $\%$ \\
\hline <9 bulan & 4 & 9 \\
9-10 bulan & 40 & 91 \\
Jumlah & 44 & 100 \\
\hline & Sumber: Data Primer Peneitian, 2017
\end{tabular}

Data hasil penelitian mengenai usia ibu menunjukkan bahwa dari 44 responden, sebagian besar ibu berusia 26-30 tahun, dengan persentase sebanyak $36 \%$ atau 16 responden.

Data hasil penelitian mengenai pendidikan ibu menunjukkan bahwa dari 44 responden, sebagian besar ibu berpendidikan sampai dengan SMA yaitu sebanyak $57 \%$ atau 25 responden.

Data hasil penelitian mengenai paritas ibu menunjukkan bahwa dari 44 responden, sebagian besar ibu adalah multipara (2-4 anak) dengan persentase sebesar $55 \%$ atau 24 responden.
Data hasil penelitian mengenai usia kehamilan ketika bayi lahir menunjukkan bahwa dari 44 responden yang telah diteliti, sebagian besar ibu melahirkan pada usia kehamilan 9-10 bulan dengan persentase sebesar $91 \%$ atau 40 responden

Tabel 1.2 Data Karakteristik Bayi

\begin{tabular}{ccc}
\hline Usia Bayi & $\mathbf{N}$ & $\%$ \\
\hline <1 bulan & 5 & 11 \\
1 bulan & 10 & 23 \\
2 bulan & 8 & 18 \\
3 bulan & 7 & 16 \\
4 bulan & 14 & 32 \\
Jumlah & 44 & 100 \\
\hline Jenis Kelamin Bayi & $\mathbf{N}$ & $\%$ \\
\hline Laki-Laki & 20 & 45 \\
Perempuan & 24 & 55 \\
Jumlah & 44 & 100 \\
\hline Berat Badan Lahir Bayi & $\mathbf{N}$ & $\%$ \\
\hline <2500 gram & 4 & 9 \\
2500-4000 gram & 38 & 86 \\
Juo0 gram & 2 & 5 \\
\hline Jumlah & 44 & 100 \\
\hline
\end{tabular}

Data hasil penelitian mengenai usia bayi menunjukkan bahwa dari 44 responden, sebagian besar usia bayi berusia 4 bulan, dengan persentase sebesar $32 \%$ atau 14 responden.

Data hasil penelitian mengenai jenis kelamin bayi menunjukkan bahwa dari 44 responden, sebagian besar jenis kelamin bayi adalah perempuan, dengan persentase sebesar 55\% atau 24 bayi. Sedangkan sisanya berjenis kelamin laki-laki dengan persentase sebesar $45 \%$ atau 20 bayi.

Data hasil penelitian mengenai berat badan lahir bayi menunjukkan bahwa dari 44 responden yang telah diteliti, sebagian besar bayi lahir dengan berat badan diantara 25004000 gram dengan persentase sebesar $86 \%$ atau 38 bayi. 
Data Karakteristik Khusus

A. Pemberian ASI

Tabel 8. Distribusi Frekuensi Pemberian ASI

\begin{tabular}{ccc}
\hline Pemberian ASI & N & $\%$ \\
\hline Eksklusif & 22 & 50 \\
Non-Eksklusif & 22 & 50 \\
\hline Jumlah & 44 & 100 \\
\hline Sumber: Data Primer Penelitian, 2017
\end{tabular}

Data hasil penelitian mengenai pemberian ASI kepada bayi menunjukkan bahwa ibu yang memberikan ASI secara eksklusif sebanyak $50 \%$ atau 22 responden sedangkan ibu yang memberikan ASI secara non-eksklusif sebanyak $50 \%$ atau 22 responden.

\section{B. Rata-Rata Persentase Lemak Tubuh lbu}

Tabel 9. Distribusi Rata-Rata Persentase Lemak Tubuh lbu

\begin{tabular}{ccc}
\hline \multirow{2}{*}{$\begin{array}{c}\text { Persentase } \\
\text { Lemak }\end{array}$} & $\begin{array}{c}\text { Eksklusif } \\
(\mathbf{n = 2 2})\end{array}$ & $\begin{array}{c}\text { Non- } \\
\text { Eksklusif } \\
(\mathbf{n = 2 2})\end{array}$ \\
\cline { 2 - 3 } Tubuh Ibu & $\begin{array}{c}\text { Mean } \pm \\
\text { SD }\end{array}$ & $\begin{array}{c}\text { Mean } \pm \\
\text { SD }\end{array}$ \\
\hline$\% \quad$ Lemak & $32.88 \pm$ & $33.10 \pm$ \\
Tubuh Awal & 4.53 & 3.80 \\
$\% \quad$ Lemak & $32.71 \pm$ & $34.58 \pm$ \\
Tubuh Akhir & 5.43 & 4.27 \\
\hline \multicolumn{3}{c}{ Sumber $:$ Data Primer Penelitian, 2017 }
\end{tabular}

Data hasil penelitian mengenai rata-rata persentase lemak tubuh ibu menunjukkan bahwa ibu yang memberikan ASI secara eksklusif rata-rata persentase lemak tubuh pada awal pengukuran adalah $32,88 \%$ dan persentase lemak tubuh pada akhir pengukuran adalah $32,71 \%$.

Pada ibu yang memberikan ASI secara non-eksklusif rata-rata persentase lemak tubuh pada awal pengukuran adalah $33,10 \%$ dan pada akhir pengukuran rata-rata persentase lemak tubuhnya adalah $34,58 \%$.

\section{Rata-Rata Berat Badan Ibu}

Tabel 10. Distribusi Rata-Rata Berat Badan Ibu

\begin{tabular}{lcc}
\hline $\begin{array}{c}\text { Berat } \\
\text { Badan Ibu }\end{array}$ & $\begin{array}{c}\text { Eksklusif } \\
(\mathbf{n}=22)\end{array}$ & $\begin{array}{c}\text { Non- } \\
\text { Eksklusif } \\
(\mathbf{n}=22)\end{array}$ \\
\cline { 2 - 3 } & Mean \pm SD & Mean \pm SD \\
\hline BB ketika & $67.77 \pm$ & $66.29 \pm$ \\
hamil & 13.78 & 10.91 \\
BB setelah & $62.13 \pm$ & $62.36 \pm$ \\
melahirkan & 13.69 & 10.41 \\
BB & $60.59 \pm$ & $61.57 \pm$ \\
menyusui & 11.71 & 11.61 \\
\hline \multicolumn{2}{c}{ Sumber : Data Primer Penelitian, 2017 }
\end{tabular}

$$
\text { Data hasil penelitian }
$$

mengenai berat badan ibu menunjukkan bahwa ibu yang memberikan ASI secara eksklusif rata-rata berat badan ketika hamil adalah $66,77 \mathrm{~kg}$, berat badan setelah melahirkan rata-rata 62,13 $\mathrm{kg}$, serta berat badan ketika menyusui adalah 60,59 kg.

Pada ibu yang memberikan ASI secara non-eksklusif rata-rata berat badan ketika hamil adalah $66,29 \mathrm{~kg}$, berat badan setelah melahirkan rata-rata $62,36 \mathrm{~kg}$, sedangkan ketika menyusui ratarata berat badan adalah $61,57 \mathrm{~kg}$.

\section{Hubungan Pemberian Air Susu Ibu (ASI) dengan Perubahan Persentase Lemak Tubuh Ibu}

Data hasil penelitian mengenai perubahan persentase lemak tubuh ibu menunjukkan bahwa ibu yang memberikan ASI secara eksklusif sebagian besar persentase lemak tubuhnya mengalami penurunan yaitu sebanyak $31,8 \%$ atau 14 responden sedangkan ibu yang mengalami kenaikan persentase lemak tubuh sebanyak $18,2 \%$ atau 8 responden. 
Pada ibu yang memberikan ASI secara non-eksklusif sebagian besar persentase lemak tubuhnya mengalami kenaikan yaitu sebanyak $43,2 \%$ atau 19 responden sedangkan ibu yang mengalami penurunan persentase lemak tubuh sebanyak $6,8 \%$ atau 3 responden.

Hasil dari uji hubungan
dengan uji statistik Chi-square didapatkan hasil nilai $p$ value adalah $<0,05$ yaitu sebesar 0,001 yang artinya terdapat hubungan yang bermakna antara pemberian ASI dengan perubahan persentase lemak tubuh pada ibu menyusui di wilayah kerja Puskesmas Arjuno Kota Malang.

Penelitian ini juga menganalisis mengenai relative risk, menunjukan bahwa nilai relative risk sebesar 2,37 yang artinya ibu yang memberikan ASI secara noneksklusif memiliki peluang untuk meningkatkan presentase lemak tubuh sebesar 2,37 lebih tinggi dari pada ibu yang memberikan ASI secara ekslusif

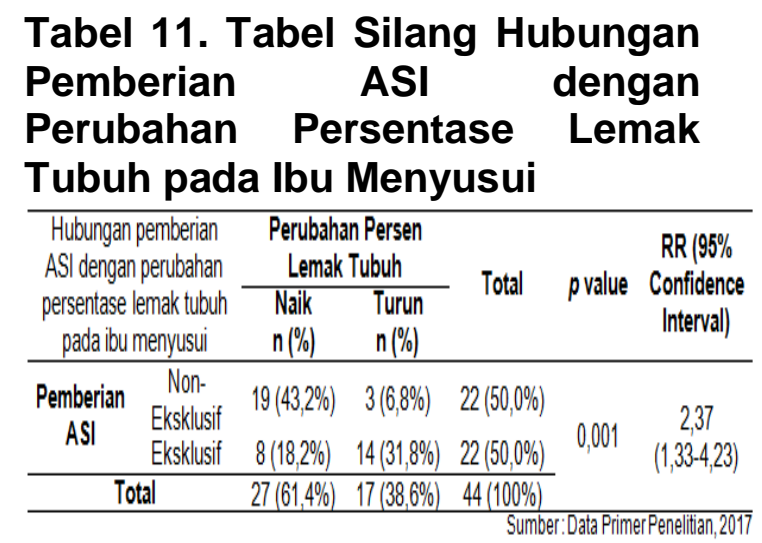

\section{PEMBAHASAN}

\section{Pemberian ASI}

Pemberian ASI kepada bayi menurut DEPKES RI, menyebutkan bahwa memberikan ASI kepada bayi sampai bayi berusia 6 bulan tanpa memberikan makanan atau minuman lain seperti susu formula, jeruk, madu, teh, air putih, dan tanpa tambahan makanan padat seperti pisang, pepaya, bubuk susu, biskuit, bubur nasi dan tim (Depkes, 2007). Hasil dari penelitian ini menunjukkan bahwa ibu yang memberikan ASI secara eksklusif maupun non-eksklusif masingmasing sebanyak $50 \%$ atau 22 responden. Menurut Sulistyoningsih (2012), dampak pemberian makanan atau minuman kepada bayi sebelum bayi berusia 6 bulan dapat menyebabkan infeksi, alergi serta ketidakmampuan bayi dalam mencerna makanan dengan baik. Beberapa penelitian membuktikan bahwa dengan memberikan ASI eksklusif dapat mengurangi tingkat kematian bayi yang disebabkan berbagai penyakit yang umum dialami oleh anak-anak seperti diare dan ISPA (Edmond et al., 2007).

\section{Perubahan Persentase Lemak Tubuh}

Persentase lemak tubuh merupakan perbandingan bobot masa jaringan lemak dan non lemak (fat free mass) pada tubuh seseorang. Hasil penelitian ini menunjukkan bahwa ibu yang memberikan ASI secara eksklusif sebagian besar persentase lemak tubuh menurun yaitu sebesar $31,8 \%$ atau 14 responden sedangkan yang mengalami kenaikan persentase lemak tubuh sebesar $18,2 \%$ atau 8 responden. Pada ibu yang memberikan ASI secara noneksklusif sebagian besar persentase lemak tubuh ibu mengalami kenaikan yaitu sebesar $43,2 \%$ atau 19 responden sedangkan yang mengalami penurunan persentase lemak tubuh sebesar $6,8 \%$ atau 3 responden. 
Menurut Gibson (2005), terdapat beberapa faktor yang dapat mempengaruhi perubahan persentase lemak tubuh pada ibu menyusui ini salah satunya adalah faktor metabolisme basal yaitu jumlah energi yang digunakan tubuh untuk bertahan hidup. Pada masa menyusui ibu membutuhkan energi cukup besar untuk memproduksi ASI. Energi tersebut dapat diambil dari cadangan lemak yang telah dibuat sejak kehamilan sehingga cadangan lemak yang telah disiapkan ibu akan menjadi berkurang dikarenakan digunakan untuk menghasilkan energi untuk memproduksi ASI.

\section{Hubungan Pemberian ASI dengan Perubahan Persentase Lemak Tubuh pada Ibu Menyusui}

Hasil analisis dengan

menggunakan uji statistik Chisquare didapatkan bahwa nilai $p=0,001$ hal ini menunjukkan bahwa terdapat hubungan yang bermakna antara pemeberian air susu ibu (ASI) dengan perubahan persentase lemak tubuh pada ibu menyusui. Selain itu, pada penelitian ini juga dianalisis mengenai relative risk, menunjukan bahwa ibu yang memberikan ASI eksklusif dapat menurunkan presentase lemak tubuh sebesar $16,8 \%$ disbanding dengan ibu yang memberikan ASI secara non-eksklusif.

Penelitian ini sejalan dengan penelitian yang dilakukan oleh Harsanti (2013) didapatkan bahwa terdapat hubungan yang bermakna antara pemberian ASI eksklusif dengan penurunan persen lemak tubuh dengan nilai $p$ value 0,007 dan nilai relative risk adalah 2,7 hal ini menyatakan bahwa ibu yang menyusui secara eksklusif akan menurunkan persen lemak tubuh sebesar 2,7 kali lebih besar dibandingkan dengan ibu yang tidak menyusui secara eksklusif.

Selama menyusui, prolaktin menekan lipogenesis pada jaringan adipose serta menurunkan aktivitas enzim kunci asetil-CoA carboxylase (ACC) serta asam lemak sintase (FAS). Hasil dari perubahan aktivitas LPL selama menyusui adalah trigliserida yang tersedia dalam sirkulasi akan diarahkan ke kelenjar susu daripada ke jaringan adiposa. Pemberian ASI yang lebih sering akan mengakibatkan peningkatan prolaktin, dimana juga akan meningkatkan aktivitas lipase lipoprotein pada jaringan mammae dan akan menghambat dalam jaringan adiposa. Apabila laktasi jarang terjadi atau tidak terjadi, tingkat prolaktin akan turun dengan cepat, sehingga endapan jaringan adiposa akan kembali seperti sebelum hamil dan kemungkinan jaringan adiposa akan dipertahankan lebih tinggi (Ling et al, 2003).

Selama menyusui, lemak yang tersimpan, dimobilisasi sebagai sumber energi untuk produksi susu, terutama di bagian femoral. Konsep ini didukung oleh penelitian yang menunjukkan bahwa aktivitas lipoprotein lipase pada adiposit di daerah femoral bertambah selama kehamilan, sedangkan terdapat peningkatan lipolisis selama menyusui. Oleh karena itu, lemak yang telah dibuat selama kehamilan akan hilang selama periode pemberian ASI eksklusif (Olmedo et al, 2016).

Mobilisasi lemak akan meningkat setelah 3 bulan pertama pascapersalinan. Pada 2 sampai 3 bulan pertama pascapersalinan, ibu yang memberi ASI mengkonsumsi 
600 sampai 800 kalori lebih sedikit daripada ibu menyusui dan secara substansial mengalami penurunan berat badan. Pada 3 sampai 6 bulan pascapersalinan, penurunan berat badan di antara ibu menyusui meningkat secara substansial. Pada periode pascapartum awal, wanita dengan gizi baik meningkatkan asupan energi dan/atau mengurangi aktivitas fisik, sementara 3 bulan berikutnya, cenderung memobilisasi lemak tubuhnya (Stuebe et al., 2009).

\section{SIMPULAN}

Hasil penelitian menunjukkan bahwa ibu yang memberikan ASI secara eksklusif maupun noneksklusif masing-masing sebesar $50 \%$ atau 22 responden. Pada ibu yang memberikan ASI secara eksklusif sebagian besar persentase lemak tubuhnya menurun yaitu sebesar $31,8 \%$ sedangkan pada ibu yang memberikan ASI secara noneksklusif sebagian besar persentase lemak tubuh ibu meningkat yaitu sebesar $43,2 \%$. Terdapat hubungan yang bermakna antara pemberian air susu ibu (ASI) dengan perubahan persentase lemak tubuh pada ibu menyusui di wilayah kerja Puskesmas Arjuno Kota Malang dengan nilai $\mathrm{p}=0,001$ dan relative risk sebesar 2,37.

\section{DAFTAR PUSTAKA}

1. Arisman., 2009. Buku Ajar IImu Gizi: Gizi dalam Daur Kehidupan, Ed. 2, EGC, Jakarta.

2. Cunningham F.G., Leveno., Hauth B., Rouse., Spong., 2012. Obstetri Williams, Vol 1, Ed. 23, EGC, Jakarta.

3. Depkes. 2007. Pedoman Pengukuran dan Pemeriksaan. Badan Penelitian dan
Pengembangan Kesehatan. Jakarta.

4. Edmond $\mathrm{KM}$, Kirkwood BR, Amenga-Etego S, Owusu-Ageyei S, Hurt LS,. Effect of Early Infant Feeding Practices on InfectionSpesific Neonatal Mortality: An Investidation of the Causal Links With Obesercational Data From Rural Ghana. American Journal Clinical Nutrition. 2007.86-89.

5. Fikawati S., Syafiq A., Karima K., 2015. Gizi Ibu dan Bayi, Ed. 1., Cet. 2., Rajawali Pers, Jakarta.

6. Gibson R.S., 2005. Principles of Nutritional Assesment Edition, Oxford University Press, New York.

7. Gigante D.P., Victora C.G., Barros F.C. Breast-Feeding Has a Limited Long-Term Effect on Anthropometry and Body Composition of Brazilian Mothers. Journal of Nutrition, 2001, 78-84.

8. Harsanti Y. 2013. Hubungan Pemberian ASI Eksklusif dengan Penurunan Persen Lemak Tubuh Ibu Menyusui. Artikel Penelitian. Tidak Diterbitkan, Fakultas Kedokteran Unviversitas Diponegoro.

9. Kemenkes RI. 2016. Pedoman Pekan ASI Sedunia. Kemenkes $\mathrm{RI}$, Jakarta.

10.Kemenkes RI. 2016. Profil Kesehatan Indonesia. Kemenkes $\mathrm{RI}$, Jakarta.

11. Kemenkes RI. 2017. Profil Kesehatan Kota Malang Tahun 2016. Kemenkes RI, Jakarta.

12.Ling C., Svensson L., Oden B., Weijdegard B., Eden., B., Eden S., et al. Identification of Functional Prolactin (PRL) Receptor Gene Expression: PRL Inhibits Lipoprotein Lipase Activity in Human White Adipose 
Tissue. The Journal of Clinical Endocrinology \& Metabolism. 2003. 88 (4) :1804-1808.

13. Maryam S., 2016. Gizi dalam Kesehatan Reproduksi, Salemba Medika, Jakarta

14. Olmedo N.L., Cordero S.H., Neufeld L.M., Guerra A.G., Rodriguez F.M., Humaran I.M.G. The Associations of Maternal Weight Change with Breastfeeding, Diet and Physical Activity during the Postpartum Period. Journal Matera Child Health. 2016. 20 :270-280.

15. Purwanti H., 2004. Konsep Penerapan ASI Eksklusif Buku Saku Untuk Bidan, Cet. 1, EGC, Jakarta.

16. Sidebottom A.C., Brown J.E., Jacobs D.R. Pregnancy-Related Changes in Body Fat. Journal of Obstetrics \& Gynecology and Reproductive Biology, 2001, 94, 216-223.

17. Sulistyoningsih H., 2012. Gizi untuk Kesehatan Ibu dan Anak, Graha IImu, Yogyakarta.

18. Stuebe A.M and Edwards J.W.R. The Reset Hypothesis: Lactation and Maternal Metabolism. American Journal of Perinatology, 2009, Vol 26. No.1. 